\title{
Uji Kesukaan dan Organoleptik Terhadap 5 kemasan dan Produk Kepulauan Seribu Secara Deskriptif
}

\author{
Chondro Suryono ${ }^{1}$, Lestari Ningrum ${ }^{2}$ \\ Triana Rosalina Dewi ${ }^{3}$ \\ ${ }^{1}$ Politeknik Pariwisata Prima Internasional, chondrostpt@yahoo.com \\ ${ }^{2}$ Sekolah Tinggi Pariwisata Trisakti, lestariningrum@stptrisakti.ac.id \\ ${ }^{3}$ Sekolah Tinggi Pariwisata Trisakti, trianadewi@stptrisakti.ac.id
}

\begin{abstract}
ABSTRAK
Sudah menjadi budaya atau kebiasaan bagi wisata lokal melakukan aktifitas wisata membeli makanan ringan baik sebagai makanan ringan dan sebagai oleh-oleh. Warga Kepulauan Seribu Jakarta Utara melihat peluang besar dalam bisnis makanan ringan ini mengingat tingkat kunjungan wisatawan ke Kepulauan Seribu yang selalu tinggi terutama di akhir pekan (BAS, 25 Desember 2017). Penelitian ini merupakan penelitian deskriptif dengan metode survei dan menggunakan uji organoleptik dan uji hedonik. Penelitian dilakukan terhadap 5 produk UKM Warga kepulauan seribu dengan berbahan dasar ikan selar, ikan teri, cumi dan buah sukun. Konsumen tertarik untuk membeli makanan ringan karena penampilan kemasan yang menarik serta merasakan produk makanan ringan yang enak. Wisatawan menyukai makanan ringan dengan kemasan yang manarik. Dari hasil penelitian ini dapat diketahui kemasan produk yang disukai berwarna biru langit. Produk yang disukai dari produk krupuk dan Abon ikan selar adalah aroma dan tekstur. Produk Stik berbahan cumi disukai pada rasa dan tekstur. Produk sambal berbahan teri dan keripik bahan sukun disukai pada tekstur dan warna.
\end{abstract}

Kata Kunci: Kemasan, makanan, organoleptik, hedonik

\begin{abstract}
It has become a cultural/ habit for local tourism to do tourism activities to buy snacks both as a snack and as souvenirs. Residents of Thousand Islands North Jakarta see great opportunities in this snack business considering the level of tourist visits to the Thousand Islands are always high, especially on the weekends. This research is a descriptive research with survey method and using organoleptic test and hedonic test. The study was conducted on 5 products of UKM of the people of the thousand islands with the basis of selar fish, anchovy, squid and sukun fruits. Consumers are interested in buying snacks because of the attractive packaging appearance and tasty snack foods. Tourists like light meals with attractive packaging. From the results of this study can be known packaging of the preferred product sky blue. The preferred products of cracker and Abon fish products are aroma and texture. Stick with products made from squid are favored on flavor and texture. Anchovy products and Sukun chips are preferred on texture and color.
\end{abstract}

Keywords : Packaging, food, Organoleptic, Hedonic

Naskah diterima : 14 April 2018, Naskah dipublikasikan : 15 September 2018

ISSN: 2355-6587, e-ISSN: 2528-2220

http://ejournal.bsi.ac.id/ejurnal/index.php/jp 


\section{PENDAHULUAN}

Makanan merupakan salah satu mata rantai dari kegiatan industri pariwisata. Makanan ringan umumnya diminati pengunjung sebagai oleh-oleh atau sekedar cemilan. Jumlah kunjungan ke kepulauan Seribu dalam data kunjungan pada 23-24 Desember 2017 sebanyak 11.232 wisatawan yang datang kesejumlah pulau di Kepulauan Seribu (BAS,25 Desember 2017), merupakan pangsa pasar yang cukup menjanjikan dan merupakan peluang bagai penduduk kepulauan Seribu khususnya wanita untuk memberdayakan sumber daya alam dan keahlian dalam pengelolahan makanan ringan berupa produk olahan dan kemasan. Dalam beberapa hasil penelitian membuktikan bahwa kemasan yang di buat dengan menarik dapat mempengaruhi keputusan pembelian (Susetyarsi,2012). Warna kemasan suatu produk oleh Yazid (2016) dianggap penting untuk diteliti pengaruhnya terhadap keputusan pembelian konsumen, Kertajaya (2008); Noviadji (2014) menyatakan bahwa Packaging sells what it protects, peran kemasan saat ini menjadi penting sebagai media komunikasi citra. Wahyuningtyas (2010) memandang perlu melakukan uji coba organoleptik terhadap bahan dari kue, demikian juga dengan pentingnya melakukan uji hedonik pada beberapa jenis makanan menurut Tarwendah (2017); Ningrum (2017); Suradi (2007); dan Wahyuningtyas dkk (2014) dapat memperkuat hasil uji bagaimana daya terima konsumen terhadap produk-produk makanan yang diteliti. Berdasarkan latar belakang, maka kepulauan Seribu mulai memikirkan kemasan yang menarik dari produksi makanan ringan yang dihasilkan, namun tetap masih memerlukan tanggapan dari para konsumen. Target pasar potensial adalah kaum muda (Kertajaya,2008), maka dalam penelitian ini responden yang di jadikan sampel adalah kaum muda. Tujuan penelitian, untuk mengukur tingkat kesukaan konsumen (hedonik) dan penilaian konsumen dari segi organoleptik makanan ringan di Kepulauan Seribu.

\section{KAJIAN LITERATUR Marketing}

Kegiatan pemasaran perusahaan harus dapat memberikan kepuasan kepada pelanggan jika menginginkan usahanya berjalan terus, atau pelanggan mempunyai pandangan yang lebih baik terhadap perusahaan lain. Kotler dan Amstrong (2004,p5) mengungkapkan bahwa "Pemasaran adalah proses sosial dan manajerial dimana individu dan kelompok memperoleh apa yang mereka butuhkan dan inginkan melalui penciptaan dan pertukaran produk dan nilai dengan yang lain".

\section{Bauran Pemasaran}

Salah satu strategi pemasaran yang digunakan adalah bauran pemasaran. Bauran pemasaran ini merupakan strategi bagaimana suatu usaha untuk dapat menarik pelanggan untuk mau membeli produk atau jasa suatu uasaha.

Kotler dan Amstrong (2004,p56) mendefinisikan bauran pemasaran sebagai seperangkat alat pemasaran taktis yang dapat digunakan perusahaan untuk terus-menerus mencapai tujuan pemasarannya di pasar sasaran".

Dari definisi di atas dapat dikatakan bahwa bauran pemasaran merupakan elemen elemen pemasaran yang mempengaruhi pasar, agar dapat menarik pasar sehingga mereka merasa puas dan perusahaan dapat meraih tujuan mereka.

\section{Kemasan}

Pengemasan (packaging) merupakan Suatu proses perancangan dan pembuatan wadah (container) atau pembungkus (wrapper) untuk suatu produk sehingga tampil menarik dan untuk dapat menarik pelanggan membeli produk tersebut.

\section{Organoleptik}

Uji organoleptik atau uji indera merupakan cara pengujian dengan menggunakan indera manusia sebagai alat utama untuk pengukuran daya penerimaan terhadap produk. Dalam penilaian bahan pangan sifat yang menentukan diterima atau tidak suatu produk adalah sifat indrawinya. Indra yang digunakan dalam menilai sifat indrawi adalah indera penglihatan, peraba, pembau dan pengecap. Sedangkan kuesioner merupakan sebuah alat bantu berupa daftar pertanyaan yang harus diisi oleh orang (responden) yang akan diukur. (Rahayu, 2001; Churchill, 2005; Ningrum. 2017,p 120).

Pada prinsipnya terdapat 3 jenis uji organoleptik, yaitu uji pembedaan (discriminative test), uji deskripsi (descriptive test) dan uji afektif (affective test). Uji afektif 
didasarkan pada pengukuran kesukaan (atau penerimaan) atau pengukuran tingkat kesukaan relatif. Pengujian Afektif yang menguji kesukaan dan/atau penerimaan terhadap suatu produk dan membutuhkan jumlah panelis tidak dilatih yang banyak yang sering dianggap untuk mewakili kelompok konsumen tertentu. Penelitian ini menggunakan uji afektif.

\section{Hedonik}

Watts et. al, 1989, p.66; Ningrum, 2017,p.120, mengungkapkan Teknik Uji Hedonik adalah "teknik yang dirancang untuk mengukur tingkat keinginan suatu produk. Skala kategori mulai dari yang sangat berbeda, karena tidak menyukai atau tidak menyukai, sangat tidak suka, dengan jumlah kategori yang beragam. Panelis menunjukkan tingkat kecintaan mereka terhadap masingmasing sampel dengan memilih kategori yang sesuai".

Uji hedonik merupakan pengujian yang paling banyak digunakan untuk mengukur tingkat kesukaan terhadap produksi. Tingkat kesukaan ini disebut skala hedonik, misalnya sangat suka, suka, agak suka, agak tidak suka, tidak suka, sangat tidak suka dan lain-lain. Skala hedonik dapat direntangkan atau diciutkan menurut rentangan skala yang dikehendaki. Dalam analisi datanya, skala hedonik ditransformasikan ke dalam skala angka menurut tingkat kesukaan (dapat 5, 7 atau 9 tingkat kesukaan). Dengan data ini dapat dilakukan analisa statistik.

Teknik Uji Hedonik dirancang untuk mengukur tingkat kesukaan terhadap suatu produk. Dalam melakukan pengolahan data hasil penelitian sifat organoleptik dapat dianalisis dengan menggunakkan teknik skoring (Amerine et al, 1995; Kusmayadi, 2004,3). Proses analisis data pada angket yang memiliki jawaban lebih dari 2 (dua) jawaban adalah dengan memberi nilai pada tiap pilihan.

\section{METODE PENELITIAN}

Penelitian ini menggunakan analisis deskriptif, menurut Sugiyono ,2008 adalah analisis yang digunakan untuk menganalisis data dengan cara mendiskriptifkan atau menggambarkan data yang telah terkumpul sebagaimana adanya tanpa bermaksud membuat kesimpulan yang berlaku untuk umum atau generalisasi. tekstur dari produk yang diuji.

Teknik sampling yang digunakan dalam penelitian ini menggunakan non probability sampling dengan jenis aksidential, dimana responden yang di pilih berdasarkan kebetulan, dan didapat 46 sample mahasiswa Sekolah Tinggi Pariwisata Trisakti jurusan diploma empat Perhotelan pada bulan Oktober tahun 2017, bersamaan dengan mahasiswa yang sedang mempelajari teknik uji coba dengan menggunakan organoleptik dan hedonik dalam mata kuliah Methodologi penelitian. Panelis seperti yang diungkapkan oleh Rahayu, 2001; Churchill, 2005; Ningrum, 2017,p.120, yaitu orang yang bertindak sebagai instrumen dalam menilai sifat organoleptik. Panelis yang di pilih dalam uji coba ini adalah panelis konsumen, Sedangkan panelis konsumen menurut Rahayu, 2001; Churchill, 2005; Ningrum, 2017,p.120, terdiri dari 30-100 orang yang tergantung pada target pemasaran suatu komoditi dan dapat ditentukan berdasarkan daerah atau kelompok tertentu, maka mahasiswa sebagai panelis dianggap sebagai panelis kategori konsumen.

Hasil jawaban dari panelis akan diberikan penilaian berdasarkan interval intrepretasi sebagai berikut :

\section{Untuk Aroma :}

$0-1,0 \quad$ Sangat tidak sedap/ wangi

$1,1-2,0$ tidak sedap/wangi

2,1 - 3,0 agak tidak sedap/wangi

$3,1-4,0 \quad$ sedap/wangi

$4,1-5,0$ sangat sedap/ wangi

\section{Untuk Rasa :}

0 - 1,0 Sangat tidak gurih/ sangat tidak pedas

$1,1-2,0$ tidak gurih/tidak pedas

2,1 - 3,0 agak gurih/ agakpedas

$3,1-4,0$ gurih/ pedas

$4,1-5,0$ sangat gurih/ sangat pedas

\section{Untuk Tekstur:}

$0 \quad-\quad 1,0 \quad$ Sangat tidak keras/tidak renyah/tidak empuk

1,1 - 2,0 tidak empuk/renyah/empuk

2,1 - 3,0 agak keras/kurang renyah/kurang empuk

3,1 - 4,0 lembut/renyah/empuk

$4,1-5,0$ sangat tidak keras/sangat empuk/sangat renyah 
Untuk warna :

$0-1,0 \quad$ Sangat tidak menggugah selera

$1,1-2,0 \quad$ tidak menggugah selera

$2,1-3,0$ agak menggugah selera

$3,1-4,0$ menggugah selera

$4,1-5,0$ sangat menggugah selera

Instrumens yang digunakan dalam penelitian merupakan pengembangan dari teori organoleptik dari unsur warna, aroma, rasa dan tekstur serta pengembangan dari teori hedonik, responden dimnta untuk menilai tingkat kesukaannya terhadap warna, aroma, rasa dan tekstur dari 5 produk hasil Kepulauan Seribu.

Instrumen organoleptik untuk warna menggunakan skala likert 5 tingkat, yaitu sangat menggugah selera sampai dengan sangat tidak menggugah selera, untuk aroma menggunakan skala likert 5 tingkat. Pilihan jawaban untuk tes organoleptik disediakan lebih dari satu, untuk antisipasi pilihan sesuai dengan jenis ke 5 produk yang berbeda-beda. Instrumen hedonik menggunakan skala likert dengan 5 tingkatan juga, yaitu dari sangat suka sampai sangat tidak suka.

Ke empat unsur aroma, rasa, tekstur dan warna merupakan bagian dari organoleptik. Uji organoleptik atau uji indera merupakan cara pengujian dengan menggunakan indera manusia sebagai alat utama untuk pengukuran daya penerimaan terhadap produk. Dalam penilaian bahan pangan sifat yang menentukan diterima atau tidak suatu produk adalah sifat indrawinya. Indra yang digunakan dalam menilai sifat indrawi adalah indera penglihatan, peraba, pembau dan pengecap. Sedangkan kuesioner merupakan sebuah alat bantu berupa daftar pertanyaan yang harus diisi oleh orang (panelis) yang akan diukur (Churchill, 2005).

Untuk instrumen dari segi kemasan, menggunakan skala likert 5 tingkatan juga dari sangat menarik untuk dibeli sampai dengan sangat tidak menarik untuk dibeli. Kemasan merupakan bagian dari bauran pemasaran, yaitu packaging, hal ini dilakukan karena uji bertujuan untuk mendapatkan tanggapan dari panelis tentang penampilan dari kemasan ke lima produk tersebut.

Dalam penelitian ini dilakukan uji reliabilitas, tujuan uji reliabilitas adalah untuk memastikan responden menjawab secara konsisten pernyataan dalam kuesioner yang diajukan, serta analisis deskriptif dilakukan untuk memberikan gambaran data tentang nilai rata-rata yang diberikan responden terhadap kemasan 5 produk milik Pemda Kepulauan Seribu melalui uji organoleptik dan hedonik dari kemasan, warna, aroma, rasa dan tekstur. Interpretasi Intrepretasi hasil interval nilai mean menurut Suharsimi, 2010, 279-285, dilihat dari banyaknya kelas yang digunakan yaitu 5, maka perhitungan intervalnya didapat dengan rumus sebagau berikut :

Hasil jawaban dari panelis akan diberikan penilaian untuk kemasan berdasarkan interval intrepretasi sebagai berikut :

0 - 1,0 Sangat tidak menarik untuk dibeli

1,1 - 2,0 tidak menarik untuk dibeli

2,1 - 3,0 agak menarik untuk dibeli

3,1 - 4,0 menarik untuk dibeli

4,1 - 5,0 sangat menarik untuk dibeli

Penilaian yang diberikan untuk uji hedonik akan dihitung secara rata-rata (mean), dengan memberikan interval intrepretasi terhadap hasil mean sebagai berikut :

0 - 1,0 digolongkan sangat tidak suka

1,1 - 2,0 digolongkan tidak suka

2,1 - 3,0 digolongkan agak suka

3,1 - 4,0 digolongkan suka

4,1 - 5,0 digolongkan sangat suka

\section{PEMBAHASAN \\ Uji Reliabilitas}

Tabel 1.

Hasil Uji Reliabelitas

\begin{tabular}{cc}
\hline $\begin{array}{c}\text { Cronbach's } \\
\text { Alpha }\end{array}$ & N of Items \\
\hline, 873 & 80 \\
\hline
\end{tabular}

Uji pertama yang dilakukan adalah uji reliabilitas. Reliabilitas adalah ukuran yang menujukkan bahwa alat ukur yang digunakan dalam penelitian keperilaku-an mempunyai keandalan sebagai alat ukur, diantaranya di ukur melalui konsistensi hasil pengukuran dari waktu ke waktu jika fenomena yang diukur tidak berubah (Sekaran, 2006, p.40; Sarjono 2011,35), yang menyatakan bahwa suatu instrumen penelitian mengindikasikan 
memiliki reliabilitas yang memadai jika koefisien alpha Cronbach lebih besar atau sama dengan 0,70. Pada tabel 1 terlihat hasil Cronbach alfa dari 80 instrumen pernyataan yang di minta untuk diisi sesuai penilaian dari panelis adalah 0,873 , hal ini berarti bahwa ke 46 panelis dapat menjawab secara konsisten dari pertanyaan satu ke pernyataan yang lainnya. 80 items pernyataan keseluruhan dari items indikator dalam kuesioner baik tentang kemasan, organoleptik maupun tentang hedonik.

\section{Data Biografi Responden}

\begin{tabular}{|c|c|c|c|}
\hline & & Frequency & Percent \\
\hline Valid & $\begin{array}{l}15-49 \\
\text { tahun }\end{array}$ & 46 & 100,0 \\
\hline
\end{tabular}

Keseluruhan panelis memang sengaja dipilih dalam rentang usia tersebut. Umur merupakan variabel yang selalu diperhatikan pada setiap penelitian. Umur menurut tingkat kedewasaan yaitu usia 0-14 tahun termasuk bayi dan anakanak, usia 15-49 tahun termasuk orang muda dan dewasa, dan usia 50 tahun ke atas termasuk orang tua. Secara umum kondisi fisik seseorang yang telah memasuki masa lanjut usia 52 mengalami penurunan. Hal ini dapat dilihat dari beberapa perubahan diantaranya perubahan panca indera yang meliputi penglihatan, pendengaran, penciuman, perasa. Perubahan-perubahan tersebut pada umumnya mengarah pada kemunduran kesehatan fisik dan psikis yang akhirnya akan berpengaruh juga pada aktivitas ekonomi dan sosial (Notoatmodjo, 2007,15). Pada uji daya terima, umur mempengaruhi hasil dan uji tersebut. Panelis dengan usia yang muda yaitu panelis umur 15-49 tahun dengan usia yang tua akan berbeda terhadap penilaian daya terima. Pada panelis uji daya terima sebaiknya panelis usia muda (Kartika.,et.all 1998,1; Laksmi,2012).

Tabel 3.

Jenis Kelamin

\begin{tabular}{ccc}
\hline $\begin{array}{c}\text { Frequen } \\
\text { cy }\end{array}$ & Percent \\
\hline
\end{tabular}

\begin{tabular}{clcc}
\hline \multirow{3}{*}{ Valid } & laki-laki & 16 & 34,8 \\
\cline { 2 - 4 } & perempuan & 30 & 65,2 \\
\cline { 2 - 3 } & Total & 46 & 100,0 \\
\hline
\end{tabular}

Karakteristik jenis kelamin berbeda satu sama lain baik dalam hal menilai dari panca indera yang berdekatan dengan masalah selera. Perempuan dipercaya lebih mempunyai sensitifitas yang lebih pada alat panca inderanya.

Tabel 4.

Kebiasaan Merokok

\begin{tabular}{cccc}
\hline & & Frequency & Percent \\
\hline \multirow{3}{*}{ Valid } & Ya & 4 & 8,7 \\
\cline { 2 - 4 } & Tidak & 42 & 91,3 \\
\cline { 2 - 3 } & Total & 46 & 100,0 \\
\hline
\end{tabular}

Hasil data biografi panelis terbanyak tidak merokok, hal ini sangat baik dalam uji organoleptik karena organ tubuh khususnya mulut dan lidah sebagai alat perasa belum banyak mengalami kerusakan karena tidak merokok dari pada panelis yang merokok. Rokok merupakan salah satu zat aditif yang bila digunakan dapat mengakibatkan bahaya kesehatan bagi individu dan masyarakat. Kandungan rokok yang berupa nikotin, karbon monoksida, tar, arsenik, dll, dapat menyebabkan gangguan kesehatan (Sugeng D. Triswanto, 2007,p.68). Pada uji daya terima suatu produk pangan panelis dipilih orang yang tidak merokok. Zat-zat yang terkandung di dalam rokok akan mempengaruhi indera perasa panelis. Panelis yang mempunyai kebiasaan merokok akan mempengaruhi indera perasa panelis. Panelis yang mempunyai kebiasaan merokok akan mempengaruhi daya terima, terutama pada aspek rasa (Bambang Kartika .,et.all, 1998,16; Laksmi,2012).

Tabel 5.

Kesehatan

\begin{tabular}{cccc}
\hline & & Frequency & Percent \\
\hline \multirow{3}{*}{ Valid } & Ya & 6 & 13,0 \\
\cline { 2 - 4 } & tidak & 40 & 87,0 \\
\cline { 2 - 4 } & Total & 46 & 100,0 \\
\hline
\end{tabular}


Kondisi sehat merupakan kondisi normal dari kehidupan manusia. Sehat meliputi kondisi fisik, mental, dan sosial yang sempurna dan bukan sekedar tidak sakit atau cacat. Seseorang dalam kondisi sehat, semua indera yang dimiliki dalam kondisi normal. Berbeda dengan orang dalam keadaan sakit, salah satu organ dalam tubuhnya mengalami ketidaknormalan (Budioro,2000). Panelis dalam kondisi sakit akan mempengaruhi penilaian daya terima. Orang yang menderita sakit terutama gangguan pada indera sebaiknya tidak diikut sertakan karena berpengaruh pada hasil uji daya terima yang meliputi aspek rasa, warna, aroma, dan tekstur (Bambang Kartika, 1998,16,et.all; Laksmi,2012).

Tabel 6.

Alergi makanan berbahan ikan/laut

\begin{tabular}{cccc}
\hline & & Frequency & Percent \\
\hline \multirow{3}{*}{ Valid } & Ya & 2 & 4,3 \\
\cline { 2 - 4 } & tidak & 44 & 95,7 \\
\cline { 2 - 4 } & Total & 46 & 100,0 \\
\hline
\end{tabular}

Sebaiknya seorang panelis tidak mempunyai riwayat alergi terhadap bahan yang diujikan kepada mereka, karena dapat mempengaruhi sedikit banyaknya terhadap penilaian mereka pada uji hedoniknya.

Tabel 7.

Keadaan Buta Warna

\begin{tabular}{clcc}
\hline & & Frequency & Percent \\
\hline \multirow{4}{*}{ Valid } & 0 & 1 & 2,2 \\
\cline { 2 - 4 } & ya & 1 & 2,2 \\
\cline { 2 - 4 } & tidak & 44 & 95,7 \\
\cline { 2 - 4 } & Total & 46 & 100,0 \\
\hline
\end{tabular}

Keadaan buta warna juga sebaiknya tidak menjadi panelis, ternyata panelis dalam uji ini terdapat 1, namun tidak akan berpengarih secara signifikan terhadap hasil uji.

\section{Hasil nilai 'mean' pada 5 kemasan}

Tabel 8.

Hasil Mean pada kemasan Produk Kemasan Produk keripik Berbahan Dari Ikan Selar

\begin{tabular}{|c|c|c|}
\hline & $\begin{array}{c}\text { Kemasan } \\
\text { Produk }\end{array}$ & Kesukaan \\
\hline Valid & 46 & 46 \\
\hline Missing & 0 & 0 \\
\hline Mean & 3,91 & 3,63 \\
\hline
\end{tabular}

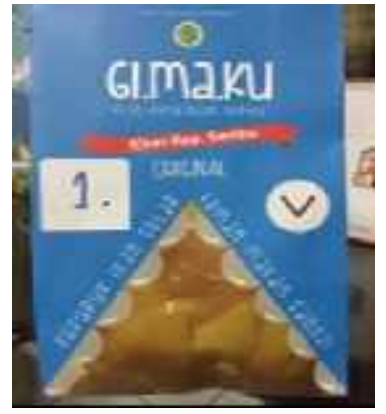

Gambar 1.

Produk Keripik Ikan Selar

Nilai rata-rata dari penilaian para panelis terhadap kemasan produk berbahan dari ikan selar dalam bentuk panganan keripik ikan, berada diangka 3,91, yang berarti menarik untuk dibeli, dan para panelis suka dengan kemasan produk ini. Maka dapat di asumsikan bahwa kemasan untuk produk berbahan ikan selar ini dengan paduan warna biru langit dapat menarik perhatian konsumen untuk membeli, tanpa/ belum merasakan produknya.

Tabel 9.

Hasil Mean pada kemasan Produk Stik Berbahan Dari Cumi

\begin{tabular}{|c|c|c|}
\hline & $\begin{array}{c}\text { Kemasan } \\
\text { Produk }\end{array}$ & Kesukaan \\
\hline Valid & 46 & 46 \\
\hline Missing & 0 & 0 \\
\hline Mean & 3,48 & 3,52 \\
\hline
\end{tabular}

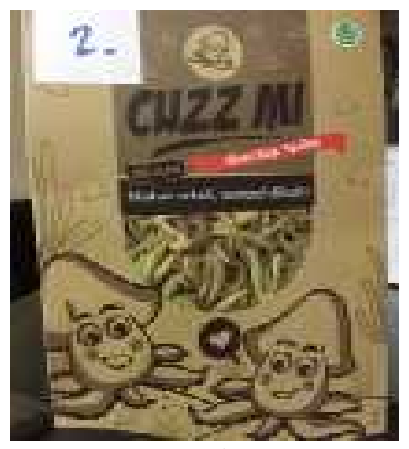

Gambar 2. 


\section{Produk Stik Berbahan Cumi}

Penilaian dari panelis untuk kemasan produk berbahan dari cumi mendapatkan nilai mean sebesar 3.48, yang berarti konsumen tertarik untuk membeli begitu melihat kemasannya dan suka dengan penampilan kemasan tersebut, dengan warna coklat muda lembut, design di tambah dengan gambar cumi kartun dan contoh dari produknya, dan pemilihan nama Cuzz Mi, ternyata menarik bagi konsumen remaja dan usia produktif.

Tabel 10.

Hasil Mean pada kemasan ProdukAbon Berbahan Dari Ikan Selar

\begin{tabular}{lcc}
\hline & Kemasan Produk & Kesukaan \\
\hline Valid & 46 & 46 \\
\hline Missing & 0 & 0 \\
\hline Mean & 3,46 & 3,46 \\
\hline
\end{tabular}

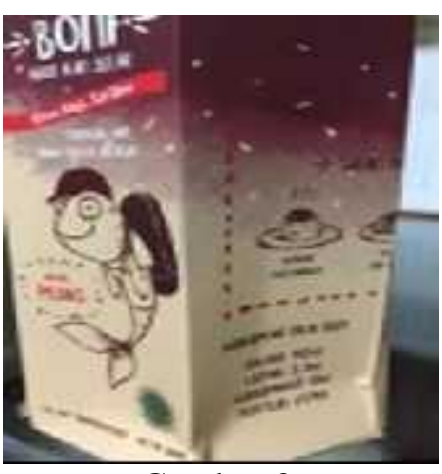

Gambar 3,

Produk Abon Berbahan Ikan Selar

Panelis memberikan penilaiannya secara ratarata terhadap kemasan produk abon dari bahan ikan selar, dengan nilai 3.46, yang berarti kemasan tersebut menarik bagi konsumen dan mereka suka. Dengan warna kemasan perpaduan warna coklat mudan dan tua serta dengan design kotak kecil yang unik ditambah dengan gambar kartun dari ikan selar yang lucu ternyata dapat menarik perhatian panelis.

Tabel 11.

Hasil Mean pada kemasan ProdukSambal Berbahan Dari Ikan Teri

\begin{tabular}{lcc}
\hline & Kemasan Produk & Kesukaan \\
\hline \multirow{2}{*}{$\mathrm{N}$ Valid } & 46 & 46 \\
\cline { 2 - 3 } Missing & 0 & 0 \\
\hline Mean & 2,74 & 3,57 \\
\hline
\end{tabular}

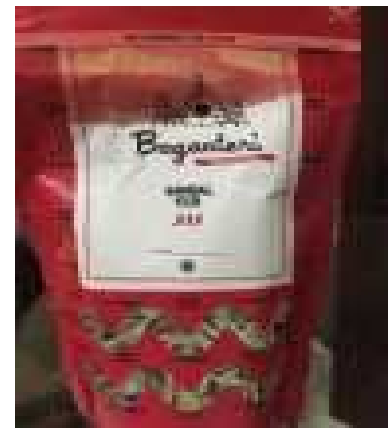

Gambar 4.

Produk sambal berbahan Teri

Kemasan produk sambal berbahan dari ikan Teri, mendapat penilaian nilai rata-rata 2,74 , yang berarti agak menarik untuk dibeli, namun panelis suka terhadap penampilan produk sambal teri yang mempunyai warna dominan merah menyala, namun dari uji kemasannya mereka belum sepenuhnya tertarik untuk membeli.

Tabel 12.

Hasil Mean pada kemasan ProdukSambal Berbahan Dari Sukun

\begin{tabular}{lcc}
\hline & Kemasan Produk & Kesukaan \\
\hline Valid & 46 & 46 \\
\hline Missing & 0 & 0 \\
\hline Mean & 3,39 & 3,46 \\
\hline
\end{tabular}

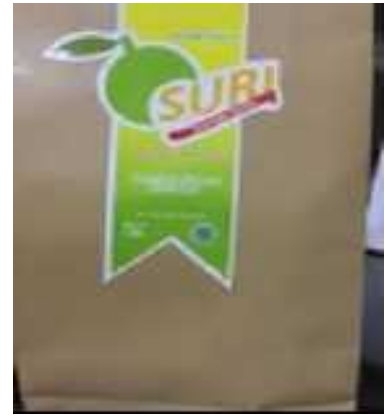

Gambar 5.

Produk Keripik Bahan Sukun 
Pada kemasan keripik berbahan sukun dinilai manarik untuk dibeli oleh panelis (3.39), dan para panelis menyukainya, dengan warna coklat muda dan design minimalis baik warha dan tampilan gambar, mampu menarik perhatian para calon konsumen.

Dari ke -5 produk, kemasan yang paling tinggi dapat menarik perhatian panelis/ konsumen adalah pada produk Kemasan Produk keripik berbahan ikan selar, yang mempunyai tampilan warna biru langit ternyata mampu menarik perhatian panelis untuk membeli. Dari kesukaan, diantara ke 5 produk UKM Warga kepulauan seribu juga memilih pada produk yang sama berbahan dari Ikan Selar, penilaian dapat berunsur subyektif dimana panelis mempunyai persepsi terhadap design kemasan, warna, gambar yang berbeda-beda, namun di ke 46 sampel panelis yang rata-rata usia produktif, menyukai dan tertarik pada kemasan produk kerupuk ikan selar.

\section{Hasil uji Organoleptik dan Hedonik pada ke - 5 produk}

Berikut akan ditampilkan hasil uji organoleptik, yang dilakukan dengan cara mencicipi dan mengkonsumsi produk dalam jumlah sedikit sebagai sampel, dengan aturan mereka tidak dalam keadaan kenyang dan lapar, dan setelah mencicipi produk panelis mentralisir panca pengecap mereka dengan cara meminum sedikit air mineral dan seterusnya.

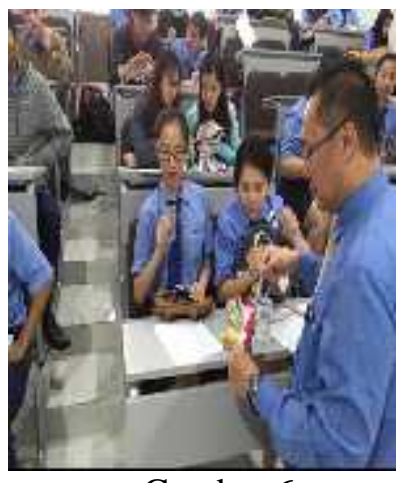

Gambar 6.

Proses Uji Organoleptik dan Hedonik

Tabel 13. Hasil uji organoleptik dan hedonik dari produk kerupuk ikan selar

\begin{tabular}{|c|c|c|c|c|c|c|c|c|}
\hline \multicolumn{9}{|c|}{ KRUPUK BAHAN IKAN SELAR } \\
\hline & $\begin{array}{c}\text { Organo } \\
\text { leptik }\end{array}$ & Hedonik & $\begin{array}{l}\text { Organo } \\
\text { leptik }\end{array}$ & Hedonik & $\begin{array}{c}\text { Organo } \\
\text { leptik }\end{array}$ & Hedoik & $\begin{array}{c}\text { Organo } \\
\text { leptik }\end{array}$ & $\begin{array}{c}\text { Hedoni } \\
\mathbf{k}\end{array}$ \\
\hline & Aroma & $\begin{array}{c}\text { Kesukaa } \\
n\end{array}$ & Rasa & $\begin{array}{c}\text { Kesukaa } \\
n\end{array}$ & Tekstur & $\begin{array}{c}\text { Kesukaa } \\
n\end{array}$ & Warna & $\begin{array}{c}\text { Kesukaa } \\
\mathrm{n}\end{array}$ \\
\hline $\mathrm{N}$ & 46 & 46 & 46 & 46 & 46 & 46 & 46 & 46 \\
\hline $\begin{array}{c}\text { Missin } \\
\mathrm{g}\end{array}$ & 0 & 0 & 0 & 0 & 0 & 0 & 0 & 0 \\
\hline $\begin{array}{c}\text { Mea } \\
n\end{array}$ & 2,76 & 2,72 & 2,70 & 2,59 & 2,74 & 2,74 & 2,48 & 2,65 \\
\hline
\end{tabular}

Panelis menilai uji organoleptik dari segi aroma dengan nilai 2.76, berarti aroma produk keripik berbahan baku dari ikan selar bagi panelis kurang wangi. Dan untuk tingkat kesukaan mereka juga menilai dalam level agak suka. Perlu di cari penyebab mengapa penilaian panelis tidak pada range angka di 3.1 keatas, apakah penyebabnya adalah pada saat pengolahannya yang tidak maksimal menggunakan bumbu yang dapat memberikan aroma wangi, ataukah karena disebabkan produk tersimpan di kemasan dalam waktu beberapa lama dapat mempengaruhi aroma produk tidak keluar, atau karena hal yang lain. Penilaian pada rasa produk berbahan dari ikan selar, mendapat nilai rata-rata 2,7 dan tingkat kesukaannya di angka 2,5. Hal ini menyatakan bahwa rasa produk ini agak gurih atau kurang gurih sebagaimana halnya dengan produk berbahan dasar ikan seharunya timbul rasa gurih yang berasal dari ikannya tersebut. Penilaian yang belum maksimal ini perlu dikaji ulang penyebabnya, apakah karena disebabkan teknik pengolahannya atau yang lainnya.

Tekstur keripik ini juga dinilai belum baik dengan nilai 2.7 maka tekstur dinilai agak keras/kurang renyah/kurang empuk. Hal ini juga sama harus di evaluasi, apakah setelah digoreng tidak mengembang sehingga kurang renyah yang dapat disebabkan proses pembuatannya yang kurang berhasil untuk sebuah produk keripik atau disebabkan hal yang lainnya.

Dari warna, produk ini masih dinilai belum dapat menggugah selera konsumen dan mereka juga belum terlalu suka. Hal ini terlihat dari warnanya yang pucat. Dari kemasan, produk ini dinilai paling menarik, namun sayang setelah di buka, dilihat dan dirasakan penilaiannya tidak sebagus penilaian pada kemasannya.

Secara marketing, apabila ingin meninggalkan kesan setelah konsumen membeli dan 
mengkonsumsi produk harus mendapatkan nilai 'aman' dari panelis di level 3,1 keatas, dengan harapan konsumen agar terkesan dengan produk dan berkeinginan untuk membeli kembali.

Tabel 14.

Hasil uji organoleptik dan kesukaan dari Produk Stik berbahan cumi

\begin{tabular}{|c|c|c|c|c|c|c|c|c|}
\hline \multicolumn{9}{|c|}{ STIK BAHAN CUMI } \\
\hline & $\begin{array}{c}\text { Organo } \\
\text { leptik }\end{array}$ & Hedonik & $\begin{array}{c}\text { Organo } \\
\text { leptik }\end{array}$ & ${ }^{0}$ Hedonik & $\begin{array}{c}\text { Organo } \\
\text { leptik }\end{array}$ & Hedoik & $\begin{array}{c}\text { Organo } \\
\text { leptik }\end{array}$ & $\begin{array}{c}\text { Hedoni } \\
\mathbf{k}\end{array}$ \\
\hline & Aroma & $\begin{array}{c}\text { Kesukaa } \\
\mathrm{n}\end{array}$ & Rasa & $\begin{array}{c}\text { Kesukaa } \\
n\end{array}$ & Tekstur & $\begin{array}{c}\text { Kesukaa } \\
n\end{array}$ & Warna & $\begin{array}{c}\text { Kesukaa } \\
\text { n }\end{array}$ \\
\hline $\mathrm{N}$ & 46 & 46 & 46 & 46 & 46 & 46 & 46 & 46 \\
\hline $\begin{array}{c}\begin{array}{c}\text { Missin } \\
\mathrm{g}\end{array} \\
\end{array}$ & 0 & 0 & 0 & 0 & 0 & 0 & 0 & 0 \\
\hline $\begin{array}{c}\text { Mea } \\
\mathrm{n} \\
\end{array}$ & 3,52 & 3,37 & 3,70 & 3,89 & 3,48 & 3,72 & 3,61 & 3,63 \\
\hline
\end{tabular}

Untuk aroma produk stik dari cumi dinilai oleh panelis/ konsumen sedap/ wangi dan mereka suka terhadap aroma produk stik cumi ini. Begitu juga dengan rasa, panelis/ konsumen menyatakan bahwa rasa stik cumi gurih dan mereka suka dengan rasa gurih tersebut dan dapat dinilai nilai kesukaan mereka lebih tinggi 1 level dengan rasa gurih yang mereka berikan. Tekstur stik juga dinilai renyah dan mereka suka, dan tingkat kesukaan yang mereka berikan untuk tekstur juga berada dalam 3 level diatas penilaian terhadap teksturnya. Untuk warna mereka memberikan penilaian produk stik cumi ini menggugah selera dan mereka meyukainya.

Tabel 15.

Hasil uji organoleptik dan kesukaan dari Produk Abon berbahan Ikan Selar

\begin{tabular}{|c|c|c|c|c|c|c|c|c|}
\hline \multicolumn{9}{|c|}{ ABON BAHAN IKAN SELAR } \\
\hline & $\begin{array}{c}\text { Organo } \\
\text { leptik }\end{array}$ & Hedonik & $\begin{array}{c}\text { Organo } \\
\text { leptik }\end{array}$ & ${ }^{0}$ Hedonik & $\begin{array}{c}\text { Organo } \\
\text { leptik }\end{array}$ & Hedoik & $\begin{array}{c}\text { Organo } \\
\text { leptik }\end{array}$ & $\begin{array}{c}\text { Hedoni } \\
\mathbf{k}\end{array}$ \\
\hline & Aroma & $\begin{array}{c}\text { Kesukaa } \\
n\end{array}$ & Rasa & $\begin{array}{c}\text { Kesukaa } \\
n\end{array}$ & Tekstur & $\begin{array}{c}\text { Kesukaa } \\
n\end{array}$ & Warna & $\begin{array}{c}\text { Kesukaa } \\
n\end{array}$ \\
\hline $\mathrm{N}$ & 46 & 46 & 46 & 46 & 46 & 46 & 46 & 46 \\
\hline $\begin{array}{c}\text { Missin } \\
\mathrm{g} \\
\end{array}$ & 0 & 0 & 0 & 0 & 0 & 0 & 0 & 0 \\
\hline $\begin{array}{c}\text { Mea } \\
n\end{array}$ & 3,52 & 3,37 & 3,09 & 3,20 & 3,83 & 3,30 & 3,33 & 3,20 \\
\hline
\end{tabular}

Untuk aroma produk abon dari bahan ikan selar dinilai oleh panelis/ konsumen sedap/ wangi dan mereka suka terhadap aroma produk abon ikan selar ini. Begitu juga dengan rasa, panelis/ konsumen menyatakan bahwa rasa abon ikan selar gurih dan mereka suka dengan rasa gurih tersebut dan dapat dinilai nilai kesukaan mereka lebih tinggi 1 level dengan rasa gurih yang mereka berikan.

Tekstur abon juga dinilai renyah dan mereka suka, dan tingkat kesukaan yang mereka berikan untuk tekstur olebih rendah dalam 5 level diatas penilaian terhadap teksturnya. Untuk warna mereka memberikan penilaian produk abon ikan selar ini menggugah selera dan mereka meyukainya.

Tabel 16.

Hasil uji organoleptik dan kesukaan dari Produk sambal berbahan Teri

\begin{tabular}{|c|c|c|c|c|c|c|c|c|}
\hline \multicolumn{9}{|c|}{ SAMBAL BAHAN IKAN TERI } \\
\hline & $\begin{array}{c}\text { Organo } \\
\text { leptik }\end{array}$ & Hedonik & $\begin{array}{c}\text { Organo } \\
\text { leptik }\end{array}$ & Hedonik & $\begin{array}{c}\text { Organo } \\
\text { leptik }\end{array}$ & Hedoik & $\begin{array}{c}\text { Organo } \\
\text { leptik }\end{array}$ & $\begin{array}{c}\text { Hedoni } \\
\mathbf{k}\end{array}$ \\
\hline & Aroma & $\begin{array}{c}\text { Kesukaa } \\
n\end{array}$ & Rasa & $\begin{array}{c}\text { Kesukaa } \\
\mathrm{n}\end{array}$ & Tekstur & $\begin{array}{c}\text { Kesukaa } \\
n\end{array}$ & Warna & $\begin{array}{c}\text { Kesukaa } \\
n\end{array}$ \\
\hline $\mathrm{N}$ & 46 & 46 & 46 & 46 & 46 & 46 & 46 & 46 \\
\hline $\begin{array}{c}\text { Missin } \\
\mathrm{g}\end{array}$ & 0 & 0 & 0 & 0 & 0 & 0 & 0 & 0 \\
\hline $\begin{array}{c}\text { Mea } \\
n\end{array}$ & 3,28 & 2,87 & 3,87 & 2,87 & 3,87 & 3,02 & 3,15 & 3,02 \\
\hline
\end{tabular}

Untuk aroma produk sambal dari bahan ikan teri dinilai oleh panelis/ konsumen sedap/ wangi dan mereka agak suka terhadap aroma produk sambal ini. Penilaian tingkat kesukaan mereka yang hanyak di level 'agak'/ 'kurang', juga perlu analisa. Tingkat kesukaan dapat mempengaruhi perilaku membeli dan keputusan membeli mereka untuk berikutnya. Begitu juga dengan rasa, panelis/ konsumen menyatakan bahwa rasa sambal terasapedas sesuai dengan level 3 yang diberikan untuk diujicobakan kepada panelis, dan ternyata mereka hanya 'agak' suka dengan rasa pedas level 3, hal ini dapat disebabkan sebagian besar panelis bukanlah konsumen yang menyukai rasa pedas. Tekstur sambal juga dinilai lembut/ halus dan mereka suka. Maka dari pengolahan sambal sudah dapat dikatakan sesuai dengan selera konsumen dari teksturnya yang tidak kasar. Untuk warna mereka memberikan penilaian produk sambal ini menggugah selera dan mereka meyukainya.

Tabel 17.

Hasil uji organoleptik dan kesukaan dari Produk Keripik Bahan Sukun

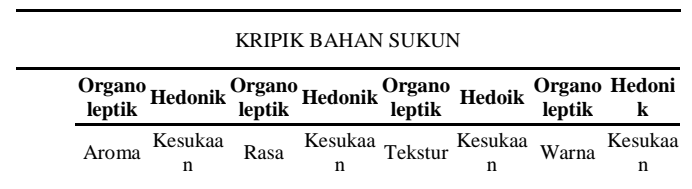




\begin{tabular}{ccccccccc}
$\mathrm{N}$ & 46 & 46 & 46 & 46 & 46 & 46 & 46 & 46 \\
\hline $\begin{array}{c}\text { Missin } \\
\mathrm{g}\end{array}$ & 0 & 0 & 0 & 0 & 0 & 0 & 0 & 0 \\
\hline $\begin{array}{c}\text { Mea } \\
\mathrm{n}\end{array}$ & 3,72 & 4,07 & 3,57 & 3,98 & 3,83 & 4,13 & 3,74 & 4,00 \\
\hline
\end{tabular}

Untuk penilaian keripik sukun, aroma dinilai sedap/ wangi dan tingkat kesukaan mereka untuk produk keripik sukun 'sangat suka'.

Rasa keripik sukun dinilai gurih dan tingkat kesukaan mereka lebih tinggi 4 level diatas penilaian rasa gurih yang mereka berikan.

Tekstur dari keripik sukun dinilai renyah dan mereka sangat menyukainya. Demikian juga dari warna merka menilai warna keripik sukun menggugah selera dan mereka sangat menyukainya.

\section{PENUTUP}

Kemasan Produk keripik berbahan ikan selar, yang mempunyai tampilan warna biru langit ternyata mampu menarik perhatian panelis untuk membeli. Dari kesukaan, diantara ke-5 produk, konsumen lebih menyukai produk yang berbahan dari Ikan Selar.

Dari hasil terendah penilaian kemasaan teri dapat disarankan seal penutup kemasan lebih kuat. Untuk kesukaan produk Abon dan Sukun disarankan agar rasa perlu diinovasi dengan berbagai rasa sesuai selera kekinian konsumen.

\section{REFERENSI}

Amerine, M.A., R.M. Pangborn, E.B. Rockssler. (1995). Principles of Sensory Evaluation of Food, Academic Press, New York and London.

BAS.( 25, Desember, 2017,). Tercatat 11 Ribu Pelancong Padati Kepulauan Seribu Long Weekend Ini.Tribunnews.com.diakses 5 Maret 2018.

http://www.tribunnews.com/metropoli $\tan / 2017 / 12 / 25 /$ tercatat-11-ribupelancong-padati-kepulauan-seribulong-weekend-ini

Budioro, (2000), Pendidikan Kesehatan dan Perilaku Kesehatan Masyarakat, Bandung: Yrama Karya.
Churchill. Gilbert A, (2005). Dasar- dasar Riset Pemasaran. alih bahasa Andrianti dkk. Jakarta:Erlangga

Kartika, B., P. Hastuti dan W. Supartono. (1998). Pedoman Uji Inderawi Bahan Pangan. Pusat Antar Universitas Pangan dan Gizi Universitas Gadjah Mada, Yogyakarta.

Kertajaya, Hermawan, (2008). New Wave Marketing.The world is still round the market is already flat.Jakarta:PT. Gramedia

Kusmayadi. (2004). Statistika Pariwisata Deskriptif, Jakarta: PT Gramedia Pustaka Utama.

Kotler, P. and Gary Amstrong. (2004). Principles of Marketing. New Jersey: Pearson Educaon, Inc.

Laksmi, Restuning Tri. (2012). Daya Ikat Air, $\mathrm{Ph}$ Dan Sifat Organoleptik Chicken Nugget Yang Disubstitusi Dengan Telur Rebus. Indonesian Jurnal Of Food Technology Vol. 1 No.1 Tahun 2012 On Line At :Http://EjournalS1.Undip.Ac.Id/Index.Php/Ijft

Ningrum, Lestari. (2017). How The Panelists Votes Chicken Ballotine With Analog Chicken Turkey and Duck. International Journal of Innovative Science and Research Technology. Volume 2, Issue 4, April-2017. ISSN No: - 2165. www.ijisrt.com.

Notoatmodjo, Soekidjo. (2003). Pendidikan Dan Perilaku Kesehatan. Rineka Cipta. Jakarta.

Noviadji, Benny Rahmawan. (2014). Desain kemasan Tradisional dalam Konteks Kekinian. Jurnal Fakultas Design. Vol.1 Nomor 01.

Rahayu, W.P. (2001). Penuntun Praktikum Penilaian Organoleptik. Teknologi Pangan dan Gizi. Fakultas Teknologi 
Pertanian Institut Pertanian. Bogor : Bogor.

Sarjono.Haryadi (2011). SPSS vs Lisrel sebuah pengantar aplikasi untuk riset. Jakarta : Salemba Empat.

Sekaran,U. (2006). Research Methods for Business. Edisi 4. Buku 2. Jakarta:Salemba (Imprint:Salemba Empat)

Sugiyono. (2008), Metode Penelitian Kuantitatif Kualitatif dan $R \& D$. Bandung: Alfabeta.

Suharsimi, Arikunto. (1992). Prosedur Penelitian Suatu Pendekatan Praktik. Jakarta: Rineka Cipta

Suradi,Kusmajadi. (2007), Tingkat kesukaan Bakso dari Berbagai Jenis Daging Melalui beberapa Pendekatan Statistik (The Hedonic Scaling of Meatball form Various Kind of Meat on Several Statistic Approached). Jurnal Ilmu ternak. Vol.7. 1, 52-57.Juni 2007.

Susetyarsi, Th.(2012). Kemasan Produk Ditinjau Dari Bahan Kemasan, Bentuk Kemasan Dan Pelabelan Pada Kemasan Pengaruhnya Terhadap Keputusan Pembelian Pada Produk Minuman Mizone Di Kota Semarang. Jurnal STIE Semarang, Vol 4, No 3, Edisi Oktober 2012 (Issn : 22527826)

Tarwendah,Ivana Putri. (2017). Jurnal Review:Studi Komparasi Atribut Sensoris dan Kesadaran Merek Produk Pangan (Comparative Study of Sensory Attributes and Brand Awareness in Food product : A Review. Jurnal Pangan dan Agroindustri Vol.5 No. 2:66-73, April 2017.

Triswanto, Sugeng D. (2007). Stop Smoking. Jakarta: Progresif Books.

Wahyuningtyas.(2010). Uji organoleptik Hasil Jadi Kue Menggunakan Bahan Non
Instant dan Instant. Binus Business Review Vol.1 No. 1 mei 2010:116125. P-ISSN:2087-1228, EISSN:2476-9053

Wahyuningtyas,Trias Septyoari Putranto dan Raden Nana Kusdiana. (2014).Uji Kesukaan Hasil jadi Kue Brownies Menggunakan Tepung Terigu dan Tepung Gandum Utuh. Binus Business Review Vol.5 No. 1 Mei 2014:57-65. P-ISSN:2087-1228, EISSN:2476-9053

Watts et. All. (1989). Basic Sensory Methods for Food Evaluation. Canada : University of Manitob

Yazid, R. K. (2016). Pengaruh Warna Kemasan, Bahan Kemasan, Desain Kemasan Terhadap Perilaku Pembelian Konsumen Mie Instan Indomie Di Surabaya (Doctoral Dissertation, STIE Perbanas Surabaya).

\section{BIODATA PENULIS}

Chondro Suryono, lulusan Doktor Pariwisata dari Universitas Gadjah Mada tahun 2016, mengampu mata kuliah Hospitality \& Tourism Marketing, Manajemen Pelayanan, Teknik Supervisi dan melakukan proceeding dengan judul "Rural Tourism as a System Inovation:Social Tranformation in a Protected Area, Atlantis Press (2017).

Lestari Ningrum, Lektor Kepala. Beberapa Karya ilmiah hingga tahun 2017 adalah:

"How The Panelists Votes Chicken Ballotine With Analog Chicken Turkey and Duck" (The Journal of Innovative Science and Research Technology), Thomson Reuters :https://goo.gl/3bkzwv.

"The Analysis of Tourism Travel Demand Model in Three Destination: Bandung, Lombok and Raja Ampat - Indonesia" (Proceeding at ASEAN Tourism Research Conference - Singapore),

"The Socialization Of ISO 9001 and SOP Implementation Learning Process By Using Kirkpatrick's Model For Students' Tourism" 
(IOSR Journal Of Humanities And Social Science),

"The Linkage of the Board of Directors and the Status of Aviation Industry Licensing Law" Jurnal Manajemen Transportasi \& Logistik (JMTranslog), And a book entitled "Usaha Perjalanan Wisata dalam Perspeltif Hukum Bisnis"/ (2004) ISBN , and Push and Pull Factors for Medical Tourism Toward Purchase Decision. 2017. Publish by Lambert Academic Publising. ISBN 978-620-2-067645.

Triana Rosalina Dewi, lulusan pasca sarjana dari Universitas Muhammadiyah Jakarta mengampu mata kuliah Ilmu Administrasi dan Manajemen, Manajemen Sumber daya Manusia serta Teknik Supervisi. Penelitian terakhir berjudul The Role of Higher Education in Tourism Village Capacity Development $n$ dalam Advances in Economics, Business and Management Research diterbitkan Atlantis Press. ISSN: 2352-5428 